\title{
"Let us call it a truthful hyperbole!" \\ A Semantic Perspective on Hyperbole in War Poetry on Iraq (2003)
}

\author{
Nawar Alobaidy \\ MA Candidate at the Department of English, College of Arts, University of Mosul, Mosul, \\ Nineveh, Iraq. \\ nawar92b92nb@gmail.com \\ Dr. Huda Halawachy \\ Department of English, College of Arts, University of Mosul, Al-Majmoo'a Al-Thaqaafiya \\ Quarter, Mosul, Ninevah, Iraq. \\ huda.halawachy@uomosul.edu.iq
}

DOI: http://doi.org/ 10.36892/ijlls.v2i4.439

\begin{tabular}{|c|c|}
\hline $\begin{array}{l}\text { Received: } \\
\text { 14/11/2020 }\end{array}$ & $\begin{array}{l}\text { Abstract } \\
\text { een known, though prevalent in everyday discourse across }\end{array}$ \\
\hline $\begin{array}{l}\text { Accepted: } \\
\text { 20/12/2020 }\end{array}$ & $\begin{array}{l}\text { cultures, hyperbole is a neglected figurative language in the linguistic and/or } \\
\text { literary sphere. In this talk, we propose a semantic taxonomy of hyperbole in } \\
\text { American and British modern war poetry showing how this taxonomy helps } \\
\text { readers figure out the poet's meaning on a deeper level via a variety of }\end{array}$ \\
\hline $\begin{array}{l}\text { Keywords: } \\
\text { figurative language; } \\
\text { semantic fields; } \\
\text { positive hyperbole; } \\
\text { negative hyperbole; } \\
\text { modern war poetry; } \\
\text { Iraq; } \\
\text { war reality }\end{array}$ & $\begin{array}{l}\text { hyperboles. The main objectives are to (1) identify the elements of such a } \\
\text { trope in the corpora, (2) approach a semantic taxonomy of hyperbolic } \\
\text { elements, and (3) come up with the true hidden messages and nature of the } \\
\text { trope in accordance with the typology of the semantic field under which the } \\
\text { trope is embraced. The corpora consist of two impressive poems - 'Abu } \\
\text { Ghraib' by Curtis D. Bennett (American), and 'A Message from Tony Blair to } \\
\text { the People of Iraq by David Roberts (British). Findings indicate that both the } \\
\text { evaluative and the quantitative dimensions are key characteristics that often } \\
\text { coincide and should, therefore, be included in every interpretation of the } \\
\text { figurative hyperbolic language in war poetry. A strong preference is also } \\
\text { observed for negative effects, auxesis, and absolute savage in the corpora, } \\
\text { though the trope sounds positive on the surface. }\end{array}$ \\
\hline
\end{tabular}

\section{BEGINNINGS}

Since ancient times, figures of speech were often studied in rhetoric, though they were ignored or reduced to literary criticism in contemporary rhetoric. In the 1980s, literary studies and other fields have revived interest in figurative language (Cano Mora, 2009, p. 25). Indeed, figurative work has emerged as a modern and distinct field known as figurative language studies. Nevertheless, much of this concern aimed at describing, how figures of speech are interpreted (Ibid). Turner (1998, p.83) stated that "the study of the figure, one of the oldest bodies of knowledge in the human sciences remains in our age still in its infancy". Within the study of figurative language, the most significant attention was paid to metaphor and verbal irony, sometimes regarded as the master tropes, whereas the study of other non-literal types had been neglected or demoted to a supplementary role. This is definitely the case with hyperbole since it is a long-ignored trope in search despite its omnipresence in daily speech. The core of the current article is to recommend a maneuver of hyperbole development by categorizing hyperbolic elements which were identified in 
the American war on Iraq poetry stanzas into the semantic fields and domains helping the audience to structure the savage reality of war; it is a pioneering attempt in the literature of hyperbole being a linguistic and literary element, as we believe.

\section{BACKGROUND}

It is worth mentioning that hyperbole has a long history of studies in the general rhetorical structure, yet the emphasis was placed on describing, classifying, and illustrating this trope. It was analyzed as a creative tool and now is associated with literary output. In literary history, some scholars made a distinction between everyday uses of overstatement and the literary or poetic form of hyperbole. In this sense, Kreuz et al (1996) examined the frequency order for the co-occurrence of the figurative language in a corpus of American short stories including idiom, metaphor, simile, understatement, irony, indirect request, and rhetorical question. The results showed that hyperbole is the most common trope which comes second after metaphor in the frequency order. In other disciplines, research on hyperbole is implied within studies of other figures, mostly irony and understatement (Colston \& Keller, 1998). On the other hand, Cano Mora (2009) introduced a corpus-based analysis of the rhetorical functions of hyperbole in ordinary conversation. She mostly concentrated on hyperbole as a long-neglected trope by non-literal language researchers who concentrated on verbal irony and metaphor. The author also realized that hyperbole is a pragmatic category that can be found in any word class or lexicogrammatical configuration.

Plausibly enough, all the empirical studies which were conducted on hyperbole cross-culturally have involved a comparison between hyperbole frequency and use in different cultures. Spitzbardt's linguistic study (1963) concentrated on hyperbole as part of the grammatical processes of intensification. Bolinger (1972), he revealed a list of adverbs and intensifying adjectives referring to the notions of absoluteness and extremity, which are obviously exaggerated. McCarthy \& Carter (2004) listed some of the most frequently used linguistic means for achieving hyperbole. They also differentiated between those words and expressions which occur with hyperbolic and non-hyperbolic function pointing out the main categories namely, expressions of the number, amount, and quantity. From a psychological perspective, most hyperbolic expressions are utilized to convey negative evaluations. In this line of thinking, Anderson \& Leaper (1998) suggested that the category of negative emotions is more varied and comparatively larger than that of positive emotions. Negative emotions were expressed for the most part in an indirect manner. Channell (1994) related exaggeration to vagueness. She says: "[A] special category of approximation is to use an exact number with a vague reading to exaggerate the quantity concerned then create hyperbole" (p.89). In a cross-cultural political study, Bany Weis (2012) presented a contrastive analysis of hyperbolic constructions in Arabic and English political speeches. The corpora were twelve political speeches of Arabic and English politicians analyzing them on linguistic, literary, rhetorical, and pragmatic levels. The results indicated that both languages share nearly the same realizations of hyperbolic expressions linguistically and pragmatically. Still, the literary and rhetoric levels in English are distinct from the Arabic data. As to hyperbole classification, Spitzbardt (1963) proposed the first classification of hyperbolic forms then it is developed further by Claridge (2011) which is syntactically oriented. 
So far, hyperbole has been investigated in different genres and from different perspectives but hardly ever in war poetry. Unlike the previous research, the present study investigates the hyperbolic expressions from a semantic viewpoint in two selected war poems. Following Spitzbardt (1965), Cano Mora (2006, pp.118-119) describes semantic field as "[c]ertain groupings of words whose lexical unity is determined by criteria of synonymy or semantic neighbourhood". Accordingly, she suggested a semantic-field typology of hyperbole in her study of hyperbole production in daily -life encounters. Readers may refer to (5.2) where details are given as far as the taxonomy is concerned.

\section{Objective}

The primary target of the current qualitative study is to identify hyperbole in modern war literary verses as describing the figure, viz. hyperbole as a type of extreme or excess which magnifies or minimizes certain real conditions or facts about the reality of American war on Iraq in 2003. This is done by following a semantic taxonomy of the hyperbolic linguistic elements, identified in the corpora, which are created in war poems as patterns of exaggeration and thereby offer an insight into the nature and characteristics of this figure through the various contexts of war.

\section{Research Questions}

In the current qualitative study, we would like to ask two guiding central questions which are:

(1) Is the semantic field a reliable maneuver in categorizing hyperbolic language in modern war poetry? and (2) Could the innovated categorization foster structuring the reality of such a trope in the war poetic context by readers?

\section{PROCEDURE, CORPORA, AND FRAMEWORK}

\subsection{PROCEDURE}

Surfing the websites enabled us to access the corpora of the study which is American war on Iraq in 2003 poetic works. Choosing poets from the West does not come from scratch. Some reasons sound justifiable:

1. Relying on our academic intuition, we feel that the savage reality of war could be more touchable in the writers' tones whose regimes started the war on Iraq in 2003.As western citizens, i.e., American and British, the two poets are aware of the military and political negative consequences of the war on Iraq. Reality is, then, in the core of their poems.

2. As Iraqi authors, we did like to avoid being subjective and emotionally involved in the process of analyzing the corpora if written by, say, Iraqi or Arab poets. It is more authentic to come up with hyperbolic expressions which the Western poets spelled out.

3. The two poets Curtis D. Bennett (A.M.) and David Robert (U.K.) were involved in war issue. For the former, he was a pilot and a marine on the ground in Vietnam; he wrote his poems from experience and deep reflection. As to the latter, he was a chairman of the justice Yugoslavia and a member of the united nations association and strongly concerned with one of war and peace for twenty years (https://www.warpoetry.uk/iraq-war-poems-2,p.2). Readers may kindly consider that being experienced in war, the two poets 
attempted to figure out the reality of American troops in Iraq utilizing hyperbole in two different poems.

\subsection{CORPORA}

Two poems namely, 'Abu Ghraib' (N.D.) for Bennett and 'A Message from Tony Blair to people of Iraq' (2003) for Robert were chosen purposefully to be investigated. These two poems are full of harsh language and imagery that were taken from real-life during the 2003 war, the images in 'Abu Ghraib' represent a kind of moral blindness - where humans are suffering from humiliation, torture, sexual, and physical abuse (Braziunaite, 2011). In the case of 'A Message from Tony Blair to the People of Iraq' was written a week after the start of the attacks by US and UK forces in March 2003). Robert said: "I wrote this bitter sarcastic poem shortly after the first bombing of Iraq feeling extremely angry about the sanctimonious arrogance, dishonesty and criminality and cruelty of Tony Blair. I feel the same way today and regret that he has not been brought to trial as a war criminal" (https://www.warpoetry.uk/iraq-war-poems-2, p. 2).

\subsection{FRAMEWORK}

As a first step, we adopted Claridge's syntactic model (2011) in identifying the hyperbolic linguistic elements in the two poetic texts as her classification scheme is interesting relying on corpora which was collected from three separate sources: (1) a sub-corpus which was derived from the spoken British National Corpus (BNC) part (demographic section), (2) newspaper data, and (3) the Santa Barbara Corpus of Spoken American English SBC, (Part I). Moving to the second step, we followed Cano Mora's semantic taxonomy (2006) to categorize the identified hyperboles into semantic fields so as to analyze the hidden true messages of hyperbole. To make the picture more revealing, it is preferrable to refer to her way of hyperbole classification. The author argued that both evaluative and quantitative dimensions have threefold distinctions. For the evaluative dimension, there are positive, negative and impact/singularity differences, whereas component and purity, quantity/measure and magnitude differences for the quantitative realm. These distinctions are briefly explained below.

The evaluative dimension includes:

(1) Positive Judgment: It transmits approval, appreciation, or praise.

(2) Negative Evaluation: It conveys frustration, criticism, or condemnation.

(3) An Area of impact and singularity: It is an in between area, i.e., between the positive and the negative evaluation classifications which conveys the idea of specialization, notability, and surprise having positive or negative connotations simultaneously. For instance, smashing performance vs. a smashing defeat.

Under quantitative dimension, on the other hand, what comes is the following three domains:

(1) Purity Domain: It consists of certain semantic fields which are:

- idea of completeness and absoluteness,

- idea of universality and non-exceptionality,

- idea of non-existence and nullity; and

- idea of veracity. 
(2) Quantity/Measured Domain:This domain includes numbers and words that are more or less standardized as measurement units; it is divided into four semantic fields as follows.

- Time measure - period units,

- Length/linear measures,

- Other numerical expressions; and

- Quantity words- the idea of accumulation.

(3) Magnitude Domain: In contrast with numerical expressions, this domain comprises natural linguistic forms cutting into two semantic fields which move around,

- the idea of greatness; and

- the idea of smallness

Which are expressed in various dimensions such as size, time, distance, etc.

It is worth mentioning that Cano Mora's analysis was extracted from the British National Corpus (BNC) a selection of more than 4, 000 written and spoken contemporary British English samples, totaling over 100 million words, stored in electronic form (Cano Mora, 2006). It is convincing to adopt such categorization as poetry speaks to man's various issues, and the savage of war is one of which!

\section{FINDINGS AND RESULTS}

\subsection{IDENTIFICATION OF HYPERBOLIC LINGUISTIC ELEMENTS}

\section{A. Bennett's Abu Ghraib}

1. Single Word Hyperbole

Photos

The photos were painfully clear

Some photos showed naked men

These photos are a metaphor (stanzas:1, 2, and4; lines:1, 9, and 41)

Helpless and powerless

Helpless, powerless to resist (stanza:4; line:36)

2. Phrasal Hyperbole

excited dogs

In total terror as excited dogs (stanza:3; line:25)

Terrified man

Still another terrified man (stanza:3; line:22)

Naked Congress

Of a feckless, hooded naked Congress (stanza:5; line:63)

\section{Clausal Hyperbole}

The photos were painfully clear, in color, and graphically detailed, in multi-pixel format

The photos were painfully clear,

In color, and graphically detailed,

In multi-pixel format (stanza:1; lines:1, 2, and3)

Painful to look at, hard to accept

Painful to look at, hard to accept. (stanza:1; line:1) 
4. Comparison

like a dog

Laying on the ground like a dog (stanza:4; line:31)

B. Roberts' A Message from Tony Blair to the People of Iraq

1. Single Word Hyperbole:

Future

the better future we have planned

Without it you would have had no future

Your future fills with hope

that for a brighter future (stanzas:2, 8, 12, and19; lines:6, 25, 40, and 99)

new

One advantage of our attack

is that we will build for you

a new Iraq

Our companies will make it all as new (stanza:16; lines: 80 and 83)

2. Phrasal Hyperbole

a safer place

our first aim is to make the world a safer place (stanza:3; line:12)

Angel face

Look into my angel face (stanza:1; line:3)

The right

I'm sure you will appreciate

that we have the right

to remove regimes

that we dislike

We have the right to assassinate

We have the right to decide your fate (stanza:5; lines:24, 27and28)

\section{Clausal Hyperbole}

we come, not to conquer, but to liberate

We come

not to conquer

but to liberate

Remember We come

not to conquer

but to liberate (stanzas:2and9; lines:8, 9, 10, 43, 44, and45)

it is not war: it's liberation

Remember, this isn't war:

it's liberation

But it isn't war

it's liberation

it isn't war

it's liberation (stanzas:10, 11, and13; lines: 58, 59 66, and 67)

4. Numerical

Thousands killed 
though I deeply mourn the thousands killed (stanza:18; line:94)

\subsection{SEMANTIC FIELDS TAXONOMY OF HYPERBOLIC LINGUISTIC ELEMENTS}

(A) Bennett's Abu Ghraib Taxonomy

Negative Evaluation

1. Idea of violence and destruction

- Photos (stanzas: 1, 2 and 4; lines:1, 9, and 41): Articulating the single word "photos", Bennett magnified the Idea of violence and destruction where he portrayed the scandal that has been happened in Abu Ghraib; the photos posted via international media shocked the whole world after they were leaked out. The Iraqi prisoners appeared in a harmful, humiliated, and inhumanity shots. Bennett addressed the American regime indirectly as if he is saying, Stop lying! Here you are the evidence! There is no way to doubt or deny these photos and facts.

- excited dogs (stanza:3; line:25): The phrasal hyperbolic expression "excited dogs" communicated the Idea of violence and destruction where Bennett described the misery that the Iraqi prisoners went through in Abu Ghraib; no one could imagine the barbarity in that spot.

\section{Idea of physical or psychic control loss}

- Helpless, powerless (stanza:4; line:36):The two single words, "helpless" and "powerless", touched upon the Idea of physical or psychic control loss where the prisoners' horrible state of having weak bodies in the sense that they were unable to act, move, and even more to think. They were totally subservient to the mercy of the war. Bennett mirrored these awful facts in the hell- prison, as we would like to refer to.

\section{Idea of frightfulness}

- Terrified man (stanza:3; line:22): The Idea of frightfulness, which the American poet, Bennett, represented in "terrified man" showed how the prisoners lived in terror every minute in Abu Ghraib; knowing nothing about their coming days in life and in prison. The Iraqi prisoners were fully confused waiting for their unknown fate.

\section{Idea of badness and evil}

- Naked Congress (stanza:5; line:63): The Idea of badness and evil is manifested in the hyperbolic phrase, "naked Congress" where Bennett portrayed the American regime and the Congress that gave the green light to start the war on Iraq. This seemed to be the cause of the hell the prisoners lived in. Now, there is no room for lies and deceit; Abu Ghraib is a piece of evidence communicating to the American public and the world that all American Congress' official statements are but lies and ways of misrepresentations, deceit and false decisions to attack and occupy Iraq.

\section{Idea of sorrow and pain}

- Painful to look at, hard to accept (stanza:1; line:1): This clausal hyperbole "painful to look at, hard to accept" indicated the Idea of sorrow and pain where Bennett communicated his sympathy and sorrow for the Iraqi prisoners in Abu Ghraib who were shown in abuse photos to the globe. 
(B) Roberts' A Message from Tony Blair to the People of Iraq Taxonomy

\section{Positive Evaluation}

\section{Idea of perfection}

- Future (stanzas:2, 8, 12, and 19; lines:6, 25, 40, and 99): The Idea of perfection is clear in the single word "future" which is repeated five times in the poem where Tony Blair promised and emphasized to the Iraqi people that all the good bright days are waiting for them after the invasion. It was exactly proved oppositely, then!

- A safer place (stanza:3; line:12): The Idea of perfection and magnificence communicated an irony in the hyperbolic phrase, namely "a safer place". As to American's official statements, the world will be a safer place after Iraq invasion. The ironic point here is how the war with all its destruction and deaths could make the world safer!

\section{Idea of splendor and beauty}

- New (stanza:16; lines:80 and 83): The Idea of splendor and beauty was expressed in a single hyperbolic word, i.e., "new" where Robert ironically showed the illusion of a new Iraq after the war as America promised the Iraqis a totally different safer brighter free country with the support of American companies to build this new Iraq!

- Angel face (stanza:1; line:3): The poet adopted the Idea of splendor and beauty in an ironic way where he described the Prime Minister, Tony Blair, as having an angel face - a hyperbolic phrase which gives the impression of goodness. This contradicts the fact that Blair's responsibility, among others, for the ruin and bloodshed in Iraq; he is a big liar; none of his promises of a new bright Iraq were accomplished!

\section{Idea of life}

- The right (stanza:5; line:24, 27 and 28): The Idea of life was expressed in the phrasal hyperbole, "the right", which is repeated three times in an ironic way where Tony Blair justified the American and British invasion of Iraq for the sake of Iraqis. They have the right to kill the Iraqi people, ruin the country, and decide Iraqis fate. All is just for a better new future echoing the ironic reality.

-We come, not to conquer, but to liberate (stanzas: 2 and 9; lines: 8, 9, 10, 43, 44 and 45): The clausal hyperbole, "we come, not to conquer, but to liberate", conveyed the Idea of life. Robert repeated the phrase twice ironically showing that it is hard to believe that the military power which came across the oceans and invaded another country, killed and arrested its people, and ruined its infrastructures intended liberating and building!

- It is not war: it's liberation (stanzas: 10, 11, and13; lines:58, 59, 66, and 67): Robert demonstrated the Idea of life in uttering the clausal hyperbole "it is not war: it's liberation". It was repeated three times. Ironically, the American poet portrayed how America occupied Iraq for many reasons of which liberation totally is not one. Freedom could never be a war consequence; chaos, destruction, death are the expected results.

\section{Quantitative Realm}

\section{The domain of quantity/measure (Numerical expressions)}

-Thousands killed (stanza:18; line:94): "Thousands killed" refers here to the Iraqi deaths whom Tony Blair feels sorry for, though he is the one who declared war on Iraq and caused these deaths! 


\section{CONCLUSION}

As shown in the Table1 below, Abu Ghraib's hyperbolic language belongs to the negative evaluative dimension. Bennett conveys violence, destruction, physical or psychic control loss, frightfulness, badness, evil, sorrow, and pain that the Iraqi prisoners feel inside Abu Ghraib; the American soldiers were the main cause. The poet also expresses his personal viewpoint on the American policy, i.e., the American Congress as a naked one just like the Iraqi prisoners who appeared naked in the photos. As an American citizen, the poet feels sorry and sympathizes with the prisoners and their pain. This sympathy appeared clearly in the poem paving the way for no glance of positive evaluation on the part of the readers, as all the types of hyperbolic language suggest in the poem.

Table 1. Distribution of Hyperbolic Linguistic Elements in Bennett's Abu Ghraib into Semantic Fields and Subfields within the Evaluative Sphere

\begin{tabular}{c|l|l}
\multicolumn{1}{c}{ No. } & \multicolumn{1}{c}{ Hyperbolic Linguistic Element } & \multicolumn{1}{c}{$\begin{array}{c}\text { Semantic Domains- Evaluative Realm } \\
\text { (Negative Evaluation) }\end{array}$} \\
\hline 1. & "Photos" & Idea of violence and destruction \\
\hline 2. & "helpless, powerless" & Idea of physical or psychic control loss \\
\hline 3. & "excited dogs" & Idea of violence and destruction \\
\hline 4. & "terrified man" & Idea of frightfulness \\
\hline 5. & "naked congress" & Idea of badness and evil \\
\hline 6. & "painful to look at, hard to accept" & Idea of sorrow and pain \\
\hline 7. & "like a dog" & Idea of violence, destruction \\
\hline
\end{tabular}

(Source: The Corpora of the Current Study)

To the contrary, Roberts' hyperbolic language belongs to positive evaluation which expresses the positive ideas of life, perfection, splendor, and magnificence which Tony Blaire repeats. In fact, we could interpret this positive view as a false glance opposite to reality. The poet here expresses an anti-war stand in an ironic sarcastic way. Iraqi people's future will never be brighter or safer after occupation. Rather, the new Iraq is full of corruption, bloodshed, and casualties, and chaos. All the promises Blaire made of liberation turned to destruction and lies leading to thousands of deaths (Tables 2 and 3 ).

Table 2. Distribution of Hyperbolic Linguistic Elements in Robert's A Message from Tony Blair to the People of Iraq Semantic Fields and Subfields within the Evaluative Sphere

\begin{tabular}{c|l|l}
\multicolumn{2}{c}{ No. Hyperbolic Expressions } & \multicolumn{1}{c}{$\begin{array}{c}\text { Semantic field - Evaluative Realm } \\
\text { (Positive Evaluation) }\end{array}$} \\
\hline 1. & "future" & Idea of perfection \\
\hline 2. & "new" & Idea of splendour \\
\hline 3. & "a safer place" & Idea of perfection, magnificence \\
\hline 4. & "angel face" & Idea of splendour, beauty \\
\hline 5. & "the right" & Idea of life \\
\hline
\end{tabular}




\begin{tabular}{c|l|l}
\hline 6. & "we come, not to conquer, but to liberate" & Idea of life \\
\hline 7. & "it is not war: it's liberation" & Idea of life \\
\hline
\end{tabular}

(Source: The Corpora of the Current Study)

Table 3. Distribution of Hyperbolic Linguistic Elements in Robert's A Message from Tony Blair to the People of Iraq Semantic Fields and Subfields within the Evaluative Sphere

Hyperbolic Expression $\quad$ Semantic Field (Quantitative Realm)

"Thousands killed" The domain of quantity/measure (numerical expressions)

(Source: The Corpora of the Current Study)

For both poets, hyperbolic language is used to structure the reality of war through their distribution into semantic fields, as we did. No more lies are accepted as war cannot make a mountain out of a molehill!

\section{REFERENCES}

Anderson, K. \& Leaper, C. (1998).Emotional talk between same and mixed gender friends: Form and function. Journal of Language and Social Psychology, 174, 419-48.

Bany Weis, Y. (2012). The Role of Hyperbolic Constructions in Selected English and Arabic Political Speeches. Ph.D. Diss. University of Sulymaniya.

Bolinger, D. (1972). Degree Words. The Hague: Mouton

Braziunaite, R. (2011). Isolated Incidents or Deliberate Policy? Media Framing of U.S. Abu Ghraib and British Detainee Abuse Scandals During the Iraq War. School of Media and Communication, Bowling Green State University, Bowling Green, Ohio.

Cano Mora, L. (2006). How to Make a Mountain out of a Molehill: A Corpus Based Pragmatic and Conversational Analysis Study of Hyperbole in Interaction. Valencia: University of Valencia Press.

(2009). All or nothing: A Semantic Analysis of Hyperbole. Revista de Lingüística y Lenguas Aplicadas, 4:25-35.

Channell, J. (1994). Vague Language. Oxford: Oxford University Press.

Claridge, C. (2011). Hyperbole in English. Cambridge: Cambridge University Press.

Colston, H. \& Keller, S. (1998). You'll Never Believe This: Irony and Hyperbole in Expressing Surprise. Journal of Psycholinguistic Research, 27: 499-513. 
Kreuz, R.; Roberts, R.; Johnson, B.; and Bertus, E. (1996). Figurative Language Occurrence and Co-occurrence in Contemporary Literature. In R. Kreuz and M.MacNealy (Ed.), Empirical Approaches to Literature and Aesthetics, (pp.83-97). Norwood, NJ: Ablex.

McCarthy, M. \& Carter, R. (2004). There's Millions of them: Hyperbole in Everyday Conversation. Journal of Pragmatics, 36 (2): 149-184.

Spitzbardt, H. (1963). Overstatement and Understatement in British and American English. Philologica Pragensia, 6: 277-286.

(1965). English Adverbs of Degree and their Semantic Fields, Philologica Pragensia 8: 349-359.

Turner, M. (1998). Figure. In A. katz (ed.), Figurative Language and Thought, (pp.4487). Oxford: Oxford University Press.

\section{WEBS CITED}

https://www.warpoetry.uk/iraq-war-poems-2). Accessed:(March 3, 2020).

\section{$\underline{\text { AUTHORS'BIOS }}$}

Nawar Alobaidy is a second-year M.A. student of English Language and Linguistics in the Department of English in the College of Arts at the University of Mosul in Mosul, Iraq.Currently, she is working on her thesis tackling hyperbole in modern war poetry(American war poetry on Iraq in 2003). Adopting critical stylistics as the umbrella freamework of the study,she is trying to prove that hyperbole is no more a lie in the context of war poetry written by An American renowned poet, Brian Turner. Her major interest is to penetrate in linguistic sphere of search which is mostly prominent in the new millennium.

Huda Halawachy received her Ph.D. in English Language and Linguistics from the University of Mosul, Mosul, Iraq in 2008. She is currently a Senior Lecturer in the Department of English in the College of Arts at the University of Mosul in Mosul, Iraq. She is teaching in the courses of undergraduate and postgraduate programs and leading research and student volunteer projects.It was the top of her arena when she joined a variety of global associations and societies as The International Ecolinguistics Association in England, Japan, and Nigeria and The International Association for Promoting Geoethics She has published on the interpretation of student and teacher silence and participated in international and local symposiums .Her interests include discourse analysis, pragmatics, children's literature, semiotics, and Eco linguistics. 
APPENDIX

\section{The Poetic Corpora: \\ 'Abu Ghraib' \\ And}

'A Message from Tony Blair to the People of Iraq

\section{A. Curtis D. Bennett's, Abu Ghraib}

The photos were painfully clear,

In color, and graphically detailed,

In multi-pixel format

From across the world.

From another faraway land

In another place, and time.

They were undeniable, uncompromising,

Painful to look at, hard to accept.

Some photos showed naked men

Wearing black hoods over their heads,

Clustered in a pile on the floor,

As an American girl grinned and pointed at their genitalia,

As if she found it somewhat lacking.

Manacled hands embracing each other

Bare skin on bare skins

In a mangled group of bodies

Lying together in a jangled, confusing heap.

They lay helpless before the Americans.

One showed a prisoner like a giant moth-man

Standing on boxes with electrodes,

Attached to his fingers.

Still another terrified man,

Backed away, handcuffed,

Cringing against the wall

In total terror as excited dogs,

Eagerly strained and barked for the prize.

Most disturbing in that sinister jail

Known in Iraq as Abu Ghraib

A smiling American soldier,

Looks down at a prisoner,

Laying on the ground like a dog,

She held a leash to his neck

She stood there stoically watching

Her captured prize of Iraqi manhood

Cowering on the cold cement. 
Helpless, powerless to resist,

Unable to act, unable to move,

Unable to think, defenseless

Totally submissive and subservient,

Totally at the mercy of the war.

These photos are a metaphor,

Of what America considers Iraq,

What we think of the Iraqi people,

Of our dominance, or our authority,

Of our cruelty, and our brutality,

Our inhumanity and callousness,

With total disregard for other peoples

Except ourselves and our selfish priorities,

Where the Military abuse their power,

Where the strong abuse the weak,

Where Leaders are beyond the law,

Beyond authority, beyond reproach

To unfortunate prisoners of war,

They appear to believe

They are answerable to no one.

A parallel metaphor emerges,

Of guards and prisoners,

Of leashes and hoods

Of the calloused indifference

The brutal treatment to Prisoners of War.

It is Cheney holding the Leash

Of a feckless, hooded naked Congress,

Secretary Rumsfeld dragging the leash

Of the military stumbling blindly behind,

President Bush leads the trio

Down his yellow brick road,

Paved with lies and misrepresentations,

False Fear, terror, deceit,

And fanciful, imagined enemies,

Dragging behind him the hooded,

Unseeing naked American masses

Down his deadly road

Of war and destruction,

All of us, unwilling participants in his War,

All of us...in America

Prisoners of War.

B. David Robert's A Message from Tony Blair to the People of Iraq

(a week after the start of the attacks by US and UK forces, March 2003)

Look into my honest eyes.

Listen to my honest lies.

Look into my angel face. 
Just hear the sincerity in my voice.

I want you all to understand the better future we have planned.

We bomb with Christian love, not Christian hate.

We come, not to conquer, but to liberate.

It is essential, and I want to make this very clear, that our first aim is to make the world a safer place. And with precision bombing you need have no fear. And though you've not actually uttered threatening words to Britain and America, or indeed the world, and though you haven't acted yet, we believe you pose a threat a threat that cannot be ignored.

I tell you frankly that so great is the threat that act we must, while there is still time, or we may live to reap the bitter harvest of regret.

I'm sure you will appreciate that we have the right to remove regimes that we dislike.

We have the right to assassinate.

We have the right to decide your fate.

So the purpose of our mission, now that war has started, is also perfectly clear: we come to bring you hope and take away your fear.

Your army, as you know, is hopelessly outgunned.

Resistance by your soldiers is completely senseless.

We'll simply massacre. We'll wipe them out.

They cannot touch us. They're defenceless.

We wreck your homes, your lives, your infrastructure.

You needed help.

Without it you would have had no future.

Our peace, justice and democracy you will soon enjoy and celebrate. Remember, we come, 
not to conquer,

but to liberate.

Your cities shake and thunder with our bombs.

Tumbling buildings. Plumes of flames.

Roaring jets and shrieking men.

The crash of glass and children's screams.

We see the mushroom clouds again.

Now you can appreciate the genius of our civilisation.

Remember, this isn't war:

it's liberation.

We destroyed your tv station. We cut your phones.

Your power and water supplies we cut.

We destroy public buildings and private homes.

You see billowing smoke and conflagration.

But it isn't war:

it's liberation.

Your hospitals overflow. They cannot cope.

We are killing you softly with our love.

Death and destruction are everywhere.

Your future fills with hope.

And if you cannot comprehend this desecration.

Just try to understand,

it isn't war:

it's liberation.

Cruise missiles, depleted uranium,

pulse, cluster and bunker buster bombs

may shock you.

And perhaps, you're just a little awed.

But please understand we come to help

and this is your reward.

Regrettably we can treat nothing as sacred:

it is a fact of war.

No artefact of God or man,

no suffering, no pain, no law

can impede the progress of our plan.

One advantage of our attack

is that we will build for you

a new Iraq.

So don't worry about the scale of the destruction.

Our companies will make it all as new

and your oil will pay for reconstruction. 
Look to the future.

Your children will not easily forget

how we came to help.

Round the clock bombing

may have left them traumatised

and perhaps a little mad,

but soon we are sure they'll realise

just what luck they've had.

Some ask if I'm untouched by human suffering.

I can tell you my sleep is undisturbed,

though I deeply mourn the thousands killed.

I am not shaken,

and I am not stirred.

So finally I say,

that for a brighter future

a little bombing is a small price to pay.

Ignore the carnage, terror and destruction.

Our purpose

is not

domination or exploitation.

This is not

a war of conquest.

It's a war of liberation. 